\title{
Translators Training: Teaching Programs, Curricula, Practices*
}

\author{
Jinyu Liu \\ Beijing Foreign Studies University, Beijing, China; \\ Inner Mongolia University, Hohhot, China
}

\begin{abstract}
This paper focuses on the investigation of translators' training programs, specifically on the statistical analysis of Canadian universities. Main issues include the current practices and sources of innovation, research problems, methodology, and research findings. As part of the big project undertaking, the current results are on the primary stage. Translation teaching in a textual and contextual vacuum may still have a place in preparing translators of the future if it is accepted for a formative academic exercise and used to reinforce the acquisition of certain structures and vocabulary.
\end{abstract}

Index Terms - translation teaching, program, curriculum, practice

\section{Training Translators: CuRrent Practices AND SOURCES OF InNOVATION}

Translation as an activity leading to a product has a tradition reaching far back to the beginnings of recorded history and beyond that to the oral tradition. It has always been essential for trading and also a fundamental component of classical education. It was not, however, until the second half of the twentieth century that developments in Translation Studies led to a more systematic view of the attempts to develop a theory of translation. There has been a boom in institutional training of translators and interpreters since the mid-twentieth century and in particular since the 1980s. This also led to a survey of the way in which it could be best taught, in order to enhance the different skills acquired in one or more foreign languages and cultures, in relation to and in conjunction with the mother tongue, for the purpose of more effective communication. The term 'training' and 'education' are both used in the literature and reflect some of the diversity of approaches to the subject. In very general terms, 'training' tends to be preferred by those who adopt a more vocational or market-driven approach to developing translator and interpreter skills, while 'education' is favored by those who situate the acquisition of these skills in the broader social context of higher or tertiary education, although this split is not entirely clear-cut. The term 'pedagogy' is sometimes used to encompass both approaches.

Professional translation has been taught at the University of Ottawa since 1936, at McGill University of Ottawa since 1936, at McGill University in Montreal since 1943, and at the Universite de Montreal since 1951. In 1968, the translation section of the linguistics department at the Universite de Montreal offered the first full-time three year programme leading to a degree in translation. Soon after, the degree became known as a BA specialization. Translation pedagogy flourished in the 1970s right across the country, but especially in Quebec and Ontario, universities began to offer translator training programs.

The rather fixed continental traditions in the field of interpreter training are in stark contrast with the liberal educational culture in the United Kingdom. A number of Universities offer translator training, but the organization and emphasis of training varies so much between different universities that it is difficult to schematize the British system. This liberal attitude also prevails to a large extent in the organization of translator training in non-Francophone parts of Canada. As the courses are mostly short (one or two years) training programs, students must possess the necessary language skills before entering the program.

In China, the history of training translators to meet social and governmental needs can be traced back to the Yuan Dynasty. After the establishment of the Chinese Republic in 1911, there was no fixed policy regarding translator training, and most of the practitioners were self-trained. Under the People's Republic of China, in-service training was provided to those chosen to work in foreign affairs-related government departments. In Hong Kong, some basic training has been made available to university students in Hong Kong since the mid-1980s. The first university degree course in translation offered by a Chinese community was the BA in Translation started in 1974 by the University of Hong Kong.

Translation courses in the Mainland China were fully integrated into the university system and linked to academic departments. The wide variety of forms is that programs can take in the undergraduate courses from the third year to the forth year. An MA course in Translation has been running at the Beijing Foreign Studies University in 1950s. In 2007, the first university degree course in translation, the BA in Translation, started, together with the professional training

\footnotetext{
* This paper marks a stage in a research that was made possible by the Philosophy and Social Sciences Research Planning Office of Inner Mongolia, China (grant \#2011C027), and supported by the Fundamental Research Funds for the Central Universities, China (grant \#2011XX006) as well. I wish here to renew my thanks to both the committees that saw the interest of this research not only for the case study at hand, but for reflecting on a field of translation training.
} 
MTI program in Translation. 13 Universities were selected across the China as the first group to open the MTI program. The growing need for professional translators has now led to the founding and expansion of programs in an increasing number of universities. By September 2010, the number has amounted to 158.

\section{PuRPOSE OF THE RESEARCH}

This research aims at investigating the state of the art in translator training programs, curricula and practices in the postgraduate level (the MA program) at Fifteen Universities and Translator and Interpreter (T\&I) Institutions in the UK, Canada, the Mainland China and Hong Kong, and assesses the degree to which their educational and professional goals are equipped to meet the challenge that perspective translators increasingly have to face in a rapidly evolving world. The survey is to observe and report on the situations where translation is taught as an end in itself rather than as a means of learning a foreign language. Centers of higher education, especially modern language faculties with established professionally oriented translation courses, have been included in the present survey to reflect the changing situation of translation pedagogy.

One of the main aims of the present survey is to shed some light on how the teaching of translation has adapted to the changing conditions of the professional world and to the demands facing translators today. What emerged is a general trend on the part of the majority of institutions to introduce a translation training component into their curricula to satisfy not only market needs but also the growing demands within higher education for professionally oriented degrees. Much still to be done before the teaching of translation in higher education can really be said to be in line with real-world criteria and before all the institutions that have a translation component in their curricular accept the fact that training translators constitutes a serious pedagogical challenge.

In addition, the research to present a methodology for discussion, to share experience and good practice and to offer individual, tried and tested teaching methods for discussion, as well as in order to permit further testing and evaluation of the wider implications. It is thus expected that the research outcomes will contribute to the on-going discussion of the nature, development and assessment of translation competence, to the trainers, and scholars, student of translation, and decision-makers in academic settings. It is hoped that the research will also raise awareness on the part of translation initiators and users. The research also seeks to engage the interest if those Translation Studies scholars who focus on the theoretical aspects of translation to take up the challenge from their own perspectives and contribute to the development of a specific curricular which can then inform a wider audience of translation scholars, translator trainers and trainee translators.

\section{RESEARCH QUESTIONS}

(1) What does the overall translation program include in each School / Center (of / for translation studies), enrollment requirements, language proficiency, credits, assessment, etc.?

(2) How are translation modules and courses well incorporated in the curriculum design to maximize teaching efficiency? How is the curriculum designed, evaluated and improved according to students' translation competence, the social and cultural development as well as market demands? Are the courses a combination of theory and practice that will allow students to hone their translation skills?

(3) What are the particular translation teaching methods and techniques applied in class and after class? (It depends on specific languages involved in the class and student language proficiency.) How is the teaching procedure and settings arranged in class?

(4) Are there any language support programs provided? If yes, what are they? Are there any cooperations between the School and local, governmental translation sectors and agencies in the case that students have practical experiences? Is it a compulsory requirement in the program?

(5) How is the students' (translators') translation competence finally assessed? What's the theoretical and analytical basis of such assessment?

(6) What kind of jobs will the students be involved after their graduation, academically or what else? Is the translation practice and experience in local translation agencies helpful in job - hunting?

(7) Are there any staff/instructor training programs particular to those who teach translation practice? How and how often do they interact with their counterparts in and out Canada, seminars or other ways?

\section{RESEARCH Methodology}

Although much has been written on translator training, empirical research into training is arguably still in its infancy. Much of the empirical research carried out in the field of Translation Studies used inductive, theoretical and observational methods, which was heavily criticized by Toury (1995:1).

This research, however, incorporates seven main stages of the cycle through which the research process develops. It develops as follows: there is a problem, which leads to a hypothesis, which is the basis for a research design, which is followed by a measurement, data collection, data analysis, a conclusion and a possible generalization, which in turn may pose another problem, which lead to another hypothesis, and so on. At each stage, the process interacts with and is interdependent upon a theory (of translation, in this case), located at the center of the research process. The project 
overall is a qualitative and quantitative study based on theoretical analysis and statistical analysis coupled with a structured gathering of data from case studies and semi-structured questionnaires and interviews.

Questionnaire includes initial cross-section comparative questions aimed to contextualize the institution in terms of the number of teaching staff, number of student, the translator training programs, how translation -specific courses offered, academic courses on course content and structure (it greatly verified ), classroom management, the profile of the translator envisaged, the integration of professional criteria (attitudes to translation-related activities, general/specialized translation, literary/sci-tech translation, theoretical components, authentic assignments and technological aids).

\section{Key ISSUES to BE COVERED IN THE RESEARCH}

Teaching translation in a textual and contextual vacuum may still have a place in preparing translators of the future if it is accepted for what it is: namely, a formative academic exercise, used for instance, to reinforce the acquisition of certain structures and vocabulary. All-round translator education requires greater sensibility to broader communicative purposes. As Neubert (1989:5) has pointed out: "the study of translation and, in particular, the academic institutions where the practice of translation is taught do not exist in an intellectual ivory tower. They serve social needs." coming to terms with this basic concept is a crucial step toward adequately meeting the pedagogical challenge of training translators for the future and of ensuring more effective cross-cultural communication.

Current training practices discuss professional translating, fields of training, organization and content of courses, organizations of translating training in the fifteen cases, academic profile, and translation as prerequisite

Pedagogy translator training includes organization of classes, subject taught, course structure and workload and admission criteria, the minimum requirements for eligibility to a degree course in translation, whether an institution has entrance exam course in translation was in important background information for assessing course structure and content since much teaching methodology and class management depends in the numbers if students attending, again national education polices condition choice.

Question on the distribution of teacher-student contact hours and hours devotes to private study in terms of overall study effort hours. An important component of this section of the questionnaire is the balance between translation activities and translation-related activities in the course content insofar as it provides insights into how real-life criteria oriented toward market needs are integrated into the curriculum. The questions on translation activities are cross-referenced with a question which specifically asked whether the institutions integrated academic and professional criteria within their course content. If the answer is yes, they will be asked whether the professional criteria determine the type of text chosen as a translation assignment and whether information regarding the circumstances that initiates the translation process and all the relevant soci-cultural parameters was given as an integral part of the assignment. The aim of all these questions is again to gauge how far real-life factors are accounted for. A translation activity should reflect 'the realities of future professional needs' (Snell-Horny 1992:19), even within the setting of a training program if it is to be viewed as an authentic task.

The various institutions' position in relation to academic and professional goals will emerge from the settings of teaching. In that case whether the institutions offer both generalist and specialized courses and whether specialized courses are elective or compulsory. Closely linked to this issue is the question of how much scope is allotted to literary and/ or scientific-technical translation and whether these areas are considered as part of a continuum of text typologies or as distinct and even opposing or mutually-exclusive curricula.

This part of the research examines the translation teaching methodology adopted by the various institutions and discusses the rationale underlying features such as classroom arrangement and dynamics, attitudes toward translation and translation-related activities, the use of translation aids, and the availability of generalist and specialist courses all presuppose certain conceptions of translation and translating. More importantly, they are indicative of whether translation is envisaged as the main learning goal and what constitutes translation competence. The issue of translation activities in a professional perspective has to be discussed. The focus then lays on the methodological details of classroom dynamics, the use of translation aids within a professional framework, the theoretical and practical components in translation courses, and the way these aspects of translation teaching connect with translation competence.

The way translation is taught has important implications for students' future professions as translating is no longer an activity that is carried out in isolation. Professional translators generally contact their fellow translators and subject experts on-line and those working in or for translation agencies exchange views and information not only with their peers but also with project supervisor. The classroom dynamics that are applicable to a foreign language-learning environment, the latter two reflect a translation-specific pedagogical approach and regard the status and reliability of the translations produced by the students

Translation scholars agree that translators need to posses two basic kinds of theoretical knowledge: an operative or procedural kind of knowledge by which they know how to translate and declarative or factual knowledge which shapes and models their procedural activity and sets their skill and expertise within a systematic framework. Together, declarative and procedural knowledge enable translators to tackle the multifarious fields of discourse that come their way without necessarily having specific content-based knowledge and to undertake the problem-predicting and 
problem-solving processes that constitute the mainstay of any translation training course. Procedural knowledge or, in other words, a theory of translating, is not in itself sufficient.

The kind of competence that translators need to possess in order to practice their profession at their best and consequently regarding the type of knowledge and skills should be included within an educational program. That is to say, the program is geared towards the demands of the professional and markert needs. In Particular, discussions revolve around the way translation competence is to be defined and how it is to be distinguished from language competence. Translation competence is multifaceted and includes various components. A real act of translation presupposes that the translator has cognitive, social, and textual skills and access to appropriate stores of linguistics, cultural and real-world knowledge."

Another major development is the new working conditions incorporating ADP tools (term databases, workbench systems, computer-aided translation, information research software, etc) that will at the same time transform the translator's conditions and means of productivity and the means of communication with clients, certain transforming the traditional functions and requirements of freelance translators. The training program is highly aware of the need to incorporate computer skills in the actual practice. It is fundamental that a translator is capable of using modern information and communication technologies. In this regard, courses on CAT (Computer-aided Translation) and terminology management are indispensable. "CATTP" is short for Computer Aided Translator Training Platform. It is a course management system, especially for translator and interpreter training and writing training. CATTP is composed of two modules: Modle-based Course Management System and Language Server. With CATTP, instructors can easily manage online translation courses, create translation course resources and share all these resources within departments, universities and communities. Instructors can also set online translation assignments, interpretation assignments and writing assignments. By using peer review tasks and many other ways, instructors can track students' learning process, store and manage all the teaching materials and use corpus analysis tools to study the learner translation corpus generated from students' assignments to improve translation teaching and translation research.

The focus is not to update the trainees' computer equipment, but to stress on a clear, and therefore transferable, understanding of the principles along which data bases or elaborate word processors function. Trainees who are in need of a job that include a certain amount of translating might best opt for taking advanced specialized courses in translating commercial, legal, technical, scientific, and medical documentation. It also depends on their personal interests and the types of careers or companies in which they are employed. There seems thus far to be little use of CAT and MT programs in corporate settings, given the relatively limited need for translations in these settings.

Also, there is a growing demand for the training of technical editors and technical writers. An increasing number of companies or international companies located in and out of China produce high technology products that need manuals written by professional, preferably directly in Chinese. Part of the technical writers employed by the companies are trained translators, part have a linguistics or technical training. However, universities fall to begin training technical writers within the framework of extension studies in the module, including written LSP, terminology, introduction to multimedia, information management.

\section{Further Prospects: To the SPECialization of Translation Training AND CANAdian StudieS}

The number of programs offering such training has grown considerably worldwide. New degrees are being established and curricula are undergoing profound changes. The survey aims to providing penetrating and thought-provoking data and insights into the underlying rationale of translator training programs, a rationale which is destined to survive structural changes and even to provide the conceptual framework for the new curricula.

The choice of postgraduate translator training depends on a number of criteria. National traditions play a decisive role, but also the social status of translation and the perceived need for training on the part of policy-makers. One result of this mushrooming of programs, in response to the demands of globalization of communication and the internationalization of business, has been the move towards a more formalized approach, specially aimed at training translators. This training has come to see as fundamental to its success the achievement of certain objectives relating to comprehension, transfer and message production from a socio-cultural perspective. The emergence and rapid progression of the field of Translation Studies has gone hand in hand with this development, the one making demands on the other and both co-existing in a symbolic state of interdependence.

By examining and comparing the postgraduate translation training programs in five universities of Canada, a tentative of postgraduate translation pedagogy and training model could be framed for translation program conducted in China, from the admission requirements, curriculum design, course structure and content, module requirements, language support programs, competence assessments, and professional skills etc. The research will present a reliable empirical study to arouse attention in the academic field and the Ministry of Education in China. In addition, the collaboration between Chinese universities and Canadian counterparts will be established and strengthened. More Chinese students would like to be enrolled in translation competence training program in Canada; more Canadian academicians in this field will be invited to teach or give lectures in China.

\section{REFERENCES}


[1] Bassett, Susan. (2004). Translation Studies. Shanghai: Shanghai Foreign Language Education Press.

[2] Beefy, Allison. (2003). "Designing a Foreign Language Course for Trainee Translators." Quaderns. Revista de traducció 10:41-60.

[3] Bell, R. (1991). Translation and Translating. London: Longman.

[4] Bowker, L. (2002). Computer-aided Translation Technology: A Practical Introduction. Ottawa: Ottawa University Press.

[5] Brown, James D. (2001). The Elements of Language Curriculum: A Systematic Approach to Program Development. Beijing: Foreign Language Teaching and Research Press.

[6] Chan Sin-wai. (2001). Translation in Hong Kong: Past, Present and Future. Hong Kong: The Chinese University Press.

[7] Chaudron, C. (1988). Second Language Classroom: Research on Teaching and Learning. Cambridge: Cambridge Press.

[8] Chesterman, Andrew. (1997). Memes of Translation. Amsterdam and Philadelphia: John Benjamins.

[9] Davies, Maria. (2004). "Undergraduate and Postgraduate Translation Degrees: Aims and Expectations." Translation in Undergraduate Degree Programmes. Ed. Kristen Malmkjær. Amsterdam and Philadelphia: John Benjamins.

[10] Davies, Maria." Minding the Process, Improving the Product: Alternative to Traditional Translator Training." Training for the New Millennium: Pedagogies for Translation and Interpretating. Ed.

[11] Martha Tennent. (2005). Amsterdam and Philadelphia: John Benjamins, pp. 67-82.

[12] Delisle, Jean. (1984). Bridging the Language Solitudes: Growth and Development of the Translation Bureau of the Government of Canada, 1934-84. Ottawa: Secretary of State.

[13] Delisle, Jean. (1992). "Les manuels de traduction: Essai de classification." TTR: traduction, terminologie, rédaction 5.1:17-47.

[14] Dickson, Peter, and Alister Cumming, eds. (1996). National Profiles of Language Education in 25 Countries. Berkshire, England: National Foundation for Educational Research.

[15] Dubin, Fraida, and Elite, Olshtain. (2001). Course Design.1986.Shanghai: Shanghai Foreign Language Education Press.

[16] Eisner, W. (1979).The Educational Imagination: On the Design and Evaluation of School Programs. New York: Macmillan.

[17] Ellis, Rod. (2004). Understanding Second Language Acquisition. Shanghai: Shanghai Foreign Language Education Press.

[18] Fawcett. (1987). "Putting Translation Theory to Use." Translation in the Modern Languages Degree. Ed. H. Keith and I. Mason. London: CILT, 31-38.

[19] Gardner, R., and W. Lambert. (1972). Attitudes and Motivation in Second Language Learning. Rowley, MA: Newbury House.

[20] Gentzler, Edwin. (1993). Contemporary Translation Theories. London: Routledge.

[21] Gile, D. (1995). Basic Concepts and Models for Interpreter and Translator Training. Amsterdam and Philadelphia: John Benjamins.

[22] Graves, Kathleen. (2005) Designing Language Courses: A Guide for Teachers. Beijing: Foreign Language Teaching and Research Press.

[23] Holec, H. (1979). Autonomy and Foreign Language Learning. Oxford: Pergamon.

[24] Holmes, James. (1972/1988). "The Name and Nature of Translation Studies."Translated! Papers on Literary Translation and Translation Studies. Amsterdam and Atlanta: Rodopi, pp. 66-80.

[25] Johnson, Robert. (1989). The Second Language Curriculum. Cambridge: Cambridge University Press.

[26] Kiraly, D. (1995). Pathways to Translation: Pedagogy and Progress. Kent, OH: Kent University Press.

[27] Kiraly, D. (1997). “Collaborative Learning in the Translation Practice Classroom”. Translationsdidaktik. Ed.E. Fleischmann, W.Kutz and P.A.Schmitt.Tübingen: Narr, pp.152-158.

[28] Kiraly, D. (2000). A Social Constructivist Approach to Translator Education: Empowerment from Theory to Practice. Manchester: St. Jerome Publishing.

[29] Klein-Braley, C. (1996). "Teaching Translation, a Brief for the Future." Teaching Translation in Universities: Present and Future Perspectives. Ed. P. Sewell and J. Higgins. London: AFLS-CILT, 15-29.

[30] Kussmaul, P. (1995). Training the Translator. Amsterdam and Philadelphia: John Benjamins.

[31] Legutke, M., and H. Thomas. (1991). Process and Experience in the Language Classroom. London: Longman.

[32] Li, Defeng. (2000). "Tailoring Translation Programs to Social Needs: A Survey of Professional Translators." Target: International Journal of Translation Studies 12:127-49.59

[33] Liu, Ching-chih. (1998). “Translation Syllabuses at the Tertiary Level in Hong Kong.” Translation Quarterly 9 \& 10:30-82.

[34] Munby, John. (1978). Communicative Syllabus Design. Cambridge: Cambridge University Press.

[35] Munday, Jeremy. (2001). Introducing Translation Studies: Theories and Applications. London: Routledge.

[36] Neubert, A. (1989). “Translation as Mediation.”Babel: The Cultural and Linguistic Barriers Between Nations. Ed. R.Kolmel and J. Payne. Aberdeen: Aberdeen University Press, pp.5-12.

[37] Nunan, David. (1988). Syllabus Design. Oxford: Oxford University Press.

[38] Nunan, David. (1989). Designing Tasks for the Communicative Classroom. Cambridge: Cambridge University Press.

[39] Nunan, David. (2001). The Learner-Centered Curriculum: A Study in Second Language Teaching. Shanghai: Shanghai Foreign Language Education Press.

[40] Posner, George. (2005). Analyzing the Curriculum. 3rd ed. 2003.Xi' an: Shanxi Normal University Press.

[41] Pym, A. (1998). Method in Translation History. Manchester: St. Jerome.

[42] Richards, Jack. (2000). Curriculum Development in Language Teaching. Cambridge: Cambridge University Press.

[43] Roberts, R. (1984). “Traduction et Qualitéde la Langue."Sociétédes Traducteurs du Québec/Conseil de la Langue Francaise. Québec: Editeur official du Québec, pp. 172-184.

[44] Robinson, Dauglus. (2003). Becoming a Translator: An Introduction to the Theory and Practice of Translation. 2nd ed. London: Routledge.

[45] Round, N. (1996). “'Interlocking the Voids': Knowledges of the Translator.” The Knowledges of the Translator: From Literary Interpretation to Machine Classification. Ed. M. Coulthard and P. A. Odber de Baubeta. Lewiston: Edwin Mellor Press, pp.1-30.

[46] Schaffner, C., and B. Adab, eds. (2000). Developing Translation Competence. Amsterdam and Philadelphia: John Benjamins.

[47] Snell-Hornby, M. (1992). "The Professional Translator of Tomorrow: Language Specialist or All-round Expert." Teaching 
Translation and Interpreting. Training, Talent, Experience. Ed. C. Dollerup and A. Loddegaard. Amsterdam and Philadelphia: John Benjamins, pp. 9-22.

[48] "Survey of the Canadian Translation Industry." Canadian Translation Industry Sectoral Committee, 1999. 15 Jan. 2008 〈http://www.uottawa.ca/associations/csict/represum.pdf>

[49] Taba, H. (1962). Curriculum Development—Theory and Practice. NY: Harcourt, Brace \& World, 1962.

[50] Toury, Gideon. (1995). Descriptive Translation Studies and beyond. Amsterdam: John Benjamins.

[51] Tyler, Ralph. (1969). Basic Principles of Curriculum and Instruction. Chicago: University Of Chicago Press.

[52] Tao Youlan. (1994). “Translation Studies and Textbooks.” Perspectives: Studies in Translatology 13(2005):188-204.

[53] Teichler, Ulrich. "Higher Education Policy and the World of Work. Changing Conditions and Challenges." Higher Education Policy 12:285-312.

[54] Yalden, Janice. (2001). Principles of Course Design for Language Teaching. Beijing: Foreign Language Teaching and Research Press.

Jinyu Liu is currently a Ph.D candidate in the Beijing Foreign Studies University, China, Lecturer in the English Department of the Foreign Languages College at Inner Mongolia University, China. Her academic interest includes translation pedagogy and training, East Asian translation history. 